\title{
PERBANDINGAN NILAI SUSEPTIBILITAS MAGNETIK AIR LAUT MENGGUNAKAN METODE QUINCKE DI PANTAI SUMATERA BAGIAN TENGAH
}

\author{
Muhammad Zul Ilmi Rangkuti, Salomo*, Usman Malik \\ Jurusan Fisika Fakultas Matematika dan Ilmu Pengetahuan Alam Universitas Riau \\ *E-mail korespondensi: salomo@lecturer.unri.ac.id
}

\begin{abstract}
A comparative study of the magnetic susceptibility of seawater on the west and east coast of central Sumatera using the Quincke method has been done. The amount of sea water was collected for $500 \mathrm{ml}$ of each location. The number of sample location are 24 points from three west coast of Sumatera and one from east coast Sumatera. The method used for sampling is a distance function with a range of $300 \mathrm{~m}$ from the coast. Magnetic infuction was measured using a magnetic probe sensor pasco PS-2162 with two 3000 loop solenoid. When the electric current increases then, the total magnetic induction value increase. The result showed that the magnetic susceptibility $(\chi)$ in west coast varied in the range $-1,04 \times 10^{-5}$ to $-4,53 \times 10^{-5}$. The sample is a diamagnetic material. The magnetic susceptibility $(\chi)$ in east coast also varied from $-0,5 \times 10^{-5}$ to $-1,46 \times 10^{-5}$. The sample is a diamagnetic material. Salinity and $p H$ cause differences in the magnetic susceptibility of seawater.
\end{abstract}

Keywords: Magnetic susceptibility of liquid, Magnetic induction, Seawater

\begin{abstract}
ABSTRAK
Telah dilakukan penelitian perbandingan nilai suseptibilitas magnetik air laut di pantai barat dan timur Sumatera bagian tengah menggunakan metode Quincke. Jumlah sampel yang diambil dari penelitian ini sebanyak $500 \mathrm{ml}$ tiap-tiap lokasi. Jumlah titik lokasi sampel adalah 24 didapatkan dari tiga pantai barat Sumatera bagian tengah dan satu pantai timur. Metode yang digunakan untuk pengambilan sampel adalah fungsi jarak dengan rentang $300 \mathrm{~m}$ dari tepi pantai. Induksi magnetik solenoida diukur menggunakan Probe Magnetic Pasco Ps-2162 dengan dua buah solenoid 3000 lilitan. Ketika arus dinaikkan induksi magnetik semakin besar. Nilai suseptibilitas magnetik $(\chi)$ air laut pantai barat menunjukkan rentang $-1,04 \times 10^{-5}$ sampai $-4,5 \times 10-5$. Sampel merupakan bahan diamagnetik. Nilai suseptibilitas magnetik $(\chi)$ air laut pantai timur menunjukkan rentang $-0,5 \times 10^{-5}$ sampai $-1,4 \times 10^{-5}$. Sampel merupakan bahan diamagnetik. Salinitas dan pH menyebabkan perbedaan nilai suseptibilitas magnetik air laut.
\end{abstract}

Kata kunci: Suseptibilitas magnetik cairan, Induksi magnetik, Air laut

Diterima 08-01-2020 | Disetujui 15-02-2020| Dipublikasi 31-03-2020

\section{PENDAHULUAN}

Pengamatan suhu, salinitas dan Oksigen terlarut merupakan parameter yang tidak dapat dipisahkan dalam hampir setiap penelitian di laut karena berbagai aspek distribusi parameter seperti reaksi kimia dan proses biologi merupakan fungsi dari suhu, sehingga suhu menjadi suatu variabel yang menentukan. Aspek Ekologi suhu dan Salinitas seringkali dinyatakan dalam kisaran yang berbeda di setiap perairan.

Sebaran salinitas di laut dipengaruhi oleh berbagai faktor seperti pola sirkulasi air, penguapan, curah hujan dan aliran sungai. Perairan dengan tingkat curah hujan tinggi dan dipengaruhi oleh aliran sungai memiliki salinitas yang rendah sedangkan perairan yang memiliki penguapan yang tinggi, salinitas perairannya tinggi. Selain itu pola sirkulasi 
juga berperan dalam penyebaran salinitas di suatu perairan.

Perairan Selat Malaka tergolong perairan yang dangkal, dibagian paling sempit kedalamannya meningkat secara gradual hingga $100 \mathrm{~m}$ sebelum Laut Andaman. Di dasar selat ini arus pasut sangat kuat terjadi. Pergerakan dan pertukaran massa air pada selat ini umumnya menuju ke Samudera Hindia dan terjadi sangat lemah [1].

Penelitian tentang nilai suseptibilitas cairan menunjukkan bahwa nilai suseptibilitas dari cairan MnSO4.H2O sesuai dengan densitas cairan, karena semakin banyak zat terlarut densitas cairan meningkat dan larutan akan semakin memadat. Penambahan arus pada cairan juga mengakibatkan nilai suseptibilitas cairan juga meningkat [2].

Pergerakan suatu zat dalam medan magnet ditandai dengan nilai suseptibilitas magnetiknya. Untuk zat Paramagnetik dan diamagnetik metode Quincke digunakan untuk menentukan suseptibilitas magnetik cairan. Penelitian yang dilakukan sebelumnya menujukkan nilai suseptibilas magnetik dari variasi garam pada air menunjukkan hasil yang berbeda, hal ini menunjukkan bahwa nilai suseptibilitas air juga ditentukan oleh nilai salinitas dan densitas dari air [3].

Penelitian ini akan mengetahui perbedaan nilai suseptibilitas magnetik dan sifat magnetik dari air laut di daerah pantai samudera Hindia dan juga nilai suseptibilitas magnetik dan sifat magnetik di daerah pantai selat malaka dengan menggunakan metode Quincke.

\section{TINJAUAN PUSTAKA}

\section{Diamagnetik}

Bahan diamagnetik adalah bahan yang sedikit menolak garis gaya magnetik seperti natrium, perak, bismuth, raksa, dan intan. Ketika tidak ada pengaruh medan magnet luar, momen magnetik akibat gerak orbital dan spin elektron saling meniadakan. Saat adanya pengaruh medan magnet luar maka akan timbul medan magnet dalam tetapi masih lebih kecil.

Bahan diamagnetik merupakan bahan yang memiliki nilai susptibilitas Xm negatif dan sangat kecil. Bahan diamagnetik selalu mempunyai suseptibilitas yang bernilai negatif dan tidak bergantung pada suhu dengan nilai permeabilitasnya sedikit lebih kecil [4].

\section{Paramagnetik}

Bahan paramagnetik adalah bahan yang sedikit menarik garis gaya seperti alumunium, magnesium, titanium, paltina, dan fungston. Jika tidak ada pengaruh medan magnetik luar, bahan ini tidak memperlihatkan efek magnetik karena momen magnetik total akibat orbital relatif kecil.

\section{Induksi Magnetik}

Induksi magnetik adalah timbulnya kuat medan magnet disuatu titik yang disebabkan oleh arus listrik pada penghantar dan menembus suatu bidang. Induksi magnet dapat juga disebut dengan garis-garis gaya magnet. Vektor induksi magnet dapat digambarkan sebagai garis-garis gaya magnet yang menembus bidang secara tegak lurus

Fluks magnetik adalah banyaknya jumlah garis gaya yang menembus suatu bidang secara tegak lurus. Induksi magnetik merupakan suatu kuat medan magnet di suatu titik yang disebabkan oleh arus listrik yang mengalir dalam satu penghantar dan menembus suatu bidang. Vektor medan dapat dihubungkan pada garis-garis gaya dengan cara yaitu, garis singgung pada sebuah garis induksi pada setiap titik memberikan arah B dititik itu.

\section{Suseptibilitas Magnetik}

Seluruh material atau unsur di alam semesta ini adalah magnetik, namun sifat magnetik dari material ini dapat berbeda-beda sesuai dengan responnya terhadap medan magnet yang diberikan padanya. Ukuran dari respon material terhadap medan magnetik luar yang 
digunakan dinamakan dengan suseptibilitas magnetik $\left(\chi_{\mathrm{m}}\right)$.

Suseptibilitas magnetik $\left(\chi_{\mathrm{m}}\right)$ didefenisikan sebagai perbandingan antara magnetisasi $(M)$ dengan intensitas magnet $(H)$. Secara matematis dapat ditulis sebagai berikut:

$$
\chi_{m}=\frac{M}{H}
$$

suseptibilitas merupakan suatu besaran skalar tanpa dimensi yang sangat berperan dalam pengelompokan unsur. Suseptibilitas juga dapat juga ditulis sebagai berikut:

$$
\chi_{m}=\frac{B t-B o}{B o}
$$

$B t$ adalah induksi magnetik total dari solenoid dan $B o$ adalah induksi magnetik solenoid tanpa inti. DaN nilai suseptibilitas magnetik tidak ditabelkan secara langsung namun nilai ini diberikan dalam bentuk suseptibilitas massa $\left(X_{m, \text { mass }}\right)$. Nilai ini dapat ditulis sebagai berikut:

$$
\chi_{\text {m,mass }}=\frac{X_{m}}{\rho}
$$

\section{Metode Quincke}

Metode quincke digunakan untuk menentukan kerentanan magnetik diamagnetik atau zat paramagnetik dalam bentuk cairan atau larutan encer. Metode ini didasarkan pada gaya yang dialami oleh bahan bermagnet di medan magnet yang tidak seragam. Ketika suatu objek ditempatkan di medan magnet, momen magnet di induksi didalamnya. Kerentanan magnetik adalah konstanta proporsionalitas yang tidak berdimensi dan menunjukan tingkatan magnetisasi suatu bahan sebagai respons terhadap medan magnet yang diterapkan. [3]

Persamaan menunjukkan bahwa dengan memetakan h sebagai fungsi $H^{2}$, suseptibilitas magnetik dapat ditentukan langsung dari kemiringan grafik garis lurus sebagai berikut :

$$
\chi=\frac{2 \rho g h}{H^{2}}
$$

\section{METODE PENELITIAN}

Penelitian ini telah dilaksanakan pada bulan Januari 2019 - Oktober 2019 di Laboratorium Instrumentasi dan Kemagnetan, Jurusan Fisika, Fakultas Matematika dan Ilmu Pengetahuan Alam, Universitas Riau, Pekanbaru.

Pengambilan sampel dilakukan di pantai barat dan timur Sumatera bagian tengah, yaitu Pantai Natal (Kabupaten Mandailing Natal), Pantai Gandoriah (Kabupaten Padang Pariaman), Pantia Carolina (Kota Padang) dan Pantai Selat Baru (Kabupaten Bengkalis). Terdapat enam titik pengambilan sampel di setiap pantai dengan jarak 300 meter dimulai pada titik 0 dari bibir pantai

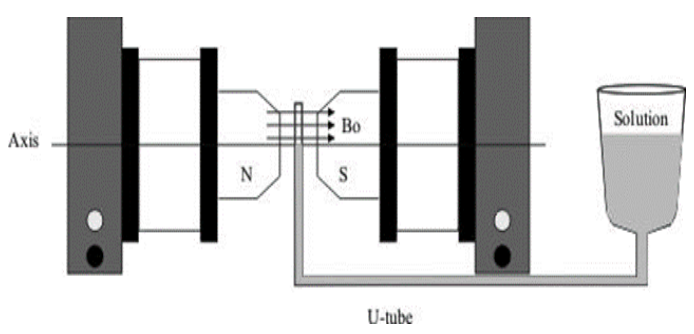

Gambar 1. Skema metode Quincke

Pengukuran dilakukan dengan mula mula rangkaian dipasangkan pada kedua solenoid yang terdiri dari kabel, power supply low voltage, dan sensor probe pasco 2162 diletakan diantara kedua solenoid dengan keadaan superposisi. Pengukuran nilai induksi magnetik setiap bagian solenoid dilakukan dengan memvariasikan arus pada power supply untuk mendapatkan nilai induksi magnetik pada setiap bagiannya, dan nilai induksi magnetik didapat menggunakan sensor probe pasco 2162 dan didukung menggunakan software data studio. Pengukuran nilai suseptibilitas gabungan kedua solenoid menggunakan probe pasco 2162 yang diletakan diantara kedua solenoid dengan keadaaan superposisi ditengan solenoid dan didukung dengan software data studio.

Data kenaikan cairan (h) yang didapat pada pipa meniscus $U$ dibandingkan dengan data induksi magnetik yang didapat dari probe pasco 2162 dan ditampilkan pada software 
data studio. Kedua data tersebut diplot grafik untuk mendapatkan nilai suseptibilitas magnetik cairan menggunakan metode Quincke

\section{HASIL DAN PEMBAHASAN}

Pengukuran nilai induksi magnetik dan ketinggian cairan terhadap pengaruh arus dilakukan menggunakan metode quincke dengan pengamatan ketinggian pada tabung $\mathrm{U}$ meniscus menggunakan loop dengan perbesaran 100 kali. Nilai induksi magnetik didapatkan dari personal computer yang sudah terinstal dengan software data studio. Sampel yang diukur merupakan sampel dari tiga lokasi pantai barat dan satu lokasi pantai timur sumatera bagian tengah.

Perubahan kenaikan cairan didapatkan dan diplot grafik kemudian dilakukan perhitungan dengan menggunakan persamaan [4].

Tabel 1. Suseptibilitas magnetik air laut pantai Natal.

\begin{tabular}{ccc}
\hline $\begin{array}{c}\text { Jarak } \\
(\mathrm{m})\end{array}$ & $\begin{array}{c}\text { Kemiringan } \\
\text { grafik } \\
\left(\times 0^{-10} \mathrm{~m}^{3} / \mathrm{A}\right)\end{array}$ & $\begin{array}{c}\text { Nilai Suseptibilitas } \\
\chi \\
\left(\times 10^{-5}\right)\end{array}$ \\
\hline 0 & $-5,32$ & $-1,04$ \\
300 & $-6,65$ & $-1,32$ \\
600 & $-7,31$ & $-1,46$ \\
900 & $-8,64$ & $-1,73$ \\
1200 & $-1,1$ & $-2,20$ \\
1500 & $-1,2$ & $-2,40$ \\
\hline
\end{tabular}

Tabel 2. Suseptibilitas magnetik air laut pantai Carolina.

\begin{tabular}{ccc}
$\begin{array}{c}\text { Jarak } \\
(\mathrm{m})\end{array}$ & $\begin{array}{c}\text { Kemiringan } \\
\text { grafik } \\
\left(\times 0^{-10} \mathrm{~m}^{3} / \mathrm{A}\right)\end{array}$ & $\begin{array}{c}\text { Nilai Suseptibilitas } \\
\chi \\
\left(\times 10^{-5}\right)\end{array}$ \\
\hline 0 & $-6,79$ & $-1,35$ \\
300 & $-8,14$ & $-1,63$ \\
600 & $-10,18$ & $-2,04$ \\
900 & $-21,7$ & $-4,35$ \\
1200 & $-22,3$ & $-4,42$ \\
1500 & $-23,75$ & $-4,53$ \\
\hline
\end{tabular}

Nilai suseptibilitas magnetik air laut pantai Barat Sumatera memiliki nilai suseptibilitas magnetik yang lebih tinggi dari pantai timur Sumatera bagian tengah dikarenakan nilai salinitas pantai bagian Barat lebih tinggi dari pantai Timur Sumatera.

Tabel 3. Suseptibilitas magnetik air laut pantai Gandoriah.

\begin{tabular}{ccc}
\hline $\begin{array}{c}\text { Jarak } \\
(\mathrm{m})\end{array}$ & $\begin{array}{c}\text { Kemiringan } \\
\text { grafik } \\
\left(\mathrm{x} \mathrm{10}^{-10} \mathrm{~m}^{3} / \mathrm{A}\right)\end{array}$ & $\begin{array}{c}\text { Nilai Suseptibilitas } \\
\chi \\
\left(\mathrm{x} 10^{-5}\right)\end{array}$ \\
\hline 0 & $-9,97$ & $-1,99$ \\
300 & $-13,5$ & $-2,61$ \\
600 & $-20,35$ & $-4,02$ \\
900 & $-21,03$ & $-4,22$ \\
1200 & $-21,72$ & $-4,36$ \\
1500 & $-22,39$ & $-4,5$ \\
\hline
\end{tabular}

Tabel 4. Suseptibilitas magnetik air laut pantai Selat Baru.

\begin{tabular}{|c|c|c|}
\hline $\begin{array}{c}\text { Jarak } \\
(\mathrm{m})\end{array}$ & $\begin{array}{c}\text { Kemiringan } \\
\text { grafik } \\
\left.\text { (x } 10^{-10} \mathrm{~m}^{3} / \mathrm{A}\right)\end{array}$ & $\begin{array}{c}\text { Nilai Suseptibilitas } \\
\chi \\
\left(\text { x } 10^{-5}\right)\end{array}$ \\
\hline 0 & $-2,61$ & $-0,512$ \\
\hline 300 & $-3,14$ & $-0,619$ \\
\hline 600 & $-4,19$ & $-0,835$ \\
\hline 900 & $-5,23$ & $-1,04$ \\
\hline 1200 & $-6,28$ & $-1,25$ \\
\hline 1500 & $-7,32$ & $-1,46$ \\
\hline
\end{tabular}

\section{KESIMPULAN}

Berdasarkan data pengukuran nilai suseptibilitas magnetik Air laut pantai Barat Sumatera memiliki nilai suseptibilitas magnetik lebih tinggi dari pantai timur Sumatera bagian tengah diduga karena lebih banyak campuran air tawar yang berasal dari sungai-sungai kea rah pantai Timur Sumatera. Perbedaan nilai susptibilitas magnetik dari kedua pantai disebabkan karena nilai salinitas dan nilia $\mathrm{pH}$ yang berbeda pada kedua pantai, semakin besar jarak pengambilan sampel maka nilai suseptibilitas juga semakin besar.

\section{REFERENSI}

1. Wyrtki, K. (1961). Physical Oceanography of the Southeast Asian Waters, Scientific Results of Marine Investigations of the South China Sea and the Gulf of Thailand. Naga Report, 2, 17-28. 
2. Jeethendra, K. P. K. (2013). Determination of Paramagnetic Susceptibility of Nickel ammonium Sulphate. LE, 13(2), 130-135.

3. Dutta, S., Mitra, A., De, R., Sardar, A., Ghosh, S., \& Maiti, T. (2013). Determination of Magnetic Susceptibility by Quincke Method. Mac Science Journal, 1, 143-151.

4. Young, H. D. \& Freedman, R. A. (2003). University Physicswith Modern Physics $11^{\text {th }}$ Edition. Boston: Addison Wesley. 